\title{
Supporting Sustainable Strategies for SMEs through Training, Cooperation and Mentoring
}

\author{
Emma O. Brien ${ }^{1}$ \& Ileana Hamburg ${ }^{2}$ \\ ${ }^{1}$ University of Limerick, Ireland \\ ${ }^{2}$ Westfälische Hochschule Gelsenkirchen, Germany \\ Correspondence: Ileana Hamburg, Westfälische Hochschule Gelsenkirchen, Germany. E-mail: hamburg@iat.eu
}

Received: January 14, 2014 Accepted: March 7, 2014 Online Published: March 27, 2014

doi:10.5539/hes.v4n2p61 URL: http://dx.doi.org/10.5539/hes.v4n2p61

\begin{abstract}
In order to remain successful and competitive in business today it is important that SMEs can sustain themselves by adapting to economic changes. SMEs have a distinct advantage over large companies in that they have less bureaucracy and hierarchical restrictions and can implement changes quickly. However often they are slow to change their way of doing business and collaborate. Through implementing training collaboration is facilitated which allows SMEs to discover new ways of doing business and practical methods of implementing these. This paper emphasises the importance of training and collaboration in sustaining SMEs going forward and outlines methods that SMEs can use to collaborate and learn to enhance their business.
\end{abstract}

Keywords: sustainable development, SMEs, learning, mentoring, communities

\section{Introduction}

Sustainability is one of the most important topics of business in the 21 th century. Idyllic and Hocketts (2002) stated that "sustainable development means adopting business strategies and activities that meet the needs of the enterprise and its stakeholders today while protecting, sustaining and enhancing the human and natural resources needed in the future".

It is important to measure progress in a company transition to sustainability but more important is to establish and discover ways which enable companies to move towards such success. Managerial experience, effort and competences are needed to implement changes in a company moving towards sustainability.

Small and medium sized companies (SMEs), are companies which employ less than 250 people (European Commission, 2003a). Despite the fact that individually they seem insignificant, combined in today's turbulent economic climate, SMEs remain vital to the European economy accounting for $98 \%$ of companies and $67 \%$ employment. (Wymenga et al., 2012). SMEs are geographically dispersed various across Europe and this reflects patterns of industrial structures, economic traditions and other framework conditions depending on their location.

Bearing in mind that 50\% of SMEs fail in the first five years (de Kok et al., 2011), it is important for Europe to ensure the survival of these companies and encourage changes within them towards sustainability. Statistics show that the probability of new entrants surviving is quite low and the chances of survival reduce the smaller the firm (European Commission, 2003b). The European Observatory report: SMEs in Europe 2003 emphasised that in times of an economic downturn, smaller companies maintain more employees than large companies. "During recessionary periods, SMEs are able to mitigate the job losses in LSEs." (European Commission, 2003b). SMEs are geared favorably towards innovation in that they are able to change direction relatively quickly as they are relatively flexible in nature. However they often lack the knowledge and expertise to assist them to fully make the transition to sustainability. For SMEs start-up or existing business, mentors can play a critical role in supporting the management teams is successfully driving the business toward sustainability.

Research has illustrated a positive relationship between training and firm productivity (Blundell et al., 1999; Konrad \& Mangle, 2000 and phd refs). Training can also facilitate the ability of employees to adapt to changeanda/or to be innovative. (Admiraal, 2009) 
Many observers from the research community, business and government organisations have stressed the importance of employee training in improved productivity and thus to achieve competitive advantage to sustainability.

"Competitive advantage grows fundamentally out of value a firm is able to create for its buyers that exceeds the firm's cost of creating it." (Porter, 1985, p. 3)

Training can assist organisations to establish and sustain a competitive advantage by increasing productivity, quality and financial results. Management literature suggests that competitive advantage built on knowledge and skills is less visible to competitors and thus more difficult to imitate, therefore providing a base for a more robust advantage. (European Commission, 2003a)

This year NBS's SME Council highlighted the importance to SMEs in extending the business collaboration and co-operation with actors of their value chain, policy makers, researchers, clients and other SMEs to increase their chances of sustainability.

The question is can training and collaboration increase SMEs chances of sustainable development?

This paper first examines the different forms of training available in the literature and their ability to support sustainable business strategies. Then an in-depth examination of the suitability of mentoring and communities of practice as a form of collaboration for sustainable development for SMEs are explored in the context of literature. Examples of how these have been implement in a number of projects have been described.

\section{Forms of Training in SMEs}

SMEs are not organisations which failed as large organisations but many aspects are considered similar to larger organisations. In fact, qualitatively they are very different and have to be managed differently from large organisations (Garcia-Morales et al., 2007). Often they lack of information and resources (as it does they do not have the economies of scale when investing in these), have no a clear vision of sustainability (as they are concerned with survival), have a patriarchal thinking (as often there is only one investor and it is in their best interest for the company to succeed) and insufficient mechanisms of learning (due to lack of time and resources). The reasons for these are often because they do not have the time and resources to invest in long term strategies and are concerned with short term survival if they are to compete. On the other hand they are more flexible than large organisations as they do not have a large amount of stakeholders in decision making and once a decision is made they can implement the outcome very quickly.

In many cases SMEs are slow to undertake new forms of training despite the fact that some of them been proven to maintain employee productivity improving a firm's competitive advantage (Ashton \& Felstead, 1995). Stone 2010 reported, i.e., that on average $36 \%$ of SMEs do not have any formal training activities. Amongst the main reasons for this are (European Commission, 2003a; Nottingham Trent University, 2002; Storey \& Westhead, 1996; Hankinson, 1994) time, cost and lack of relevant content.

These are also results of European projects SIMPEL, ReadiSME and Net Knowing 2.0 coordinated or worked by the authors in which several surveys were conducted with SMEs regarding their barriers to training. To date many efforts to encourage SMEs to adopt training have failed miserably. E-learning has tried to address issues of time and cost, by allowing employees to access learning resources remotely. However technology has now significantly changed the way people access information, the most up to date information is dispersed and embedded in networks, websites and social media sites. In addition many SMEs do not have a dedicated human resources person or even an employee that can be charged with the responsibility of searching for relevant learning resource.

To cope with challenges posed and also to transfer to sustainability it is necessary to:

- Improve the framework conditions of training and skill development, i.e., through overcoming organisational barriers and obstacles of training, investing more in supporting training activities, developing a future-oriented sustainable human resource and competence development policy;

- Develop suitable methods of training by using technical media like social media and Web 2.0 and 3.0 facilities which are based on specific needs of SMEs

- Address current and structural challenges of skill development, i.e., new qualification profile taking also into consideration demographic changes.

To support sustainable development SMEs need a targeted approach to training that can be done on the job and provide an immediate return for the company while at the same time building skills for future company requirements that may emerge. It must be possible to leverage off of other expertise in and outside the company 
to ensure the success of the training. Regarding the poor level of managerial competences and skills of many small business owners, measures should be focus on providing training and courses that will improve the human resource capacities in this context. Some forms for learning to be used in training are:

\subsection{Problem Based Learning}

Problem based learning (PBL) is a constructivist approach to learning that has been widely used and advocated in higher education. The teacher plays the role of a mentor. It is known to positively affect learning outcomes and develop the skills that are critical in today's workplace namely problem solving, logical thinking and creative thinking (Sendag, 2009)

Within a work based learning context, the student identifies a problem in the organisation and formalises a project to identify a solution (or a number of solutions) to that problem (Bell, 2010). It provides a number of benefits to SMEs (Bell, 2010; Walters \& Sirotak, 2011);

- Provides immediate Return on Investment

- Low cost

- On the job training thus the learning is highly contextualised and situated.

- Practical and related to the SMEs needs and sustaining the organisations competitive advantages.

- Encourages innovation and independent thinking.

- Provides a greater understanding of a topic due to active learning, engaging in the material.

- Increased motivation to learn thus developing a learning culture.

Develops skills in critical thinking, leadership, communication, problem solving that can be applied in future situations

Problem based learning is an ideal method of training for sustainable development as it allows the company address immediate business issues while building skills that can be transferred to future problems that may emerge

\subsection{Web Based Training}

Web-based training is any training that is delivered via web based technologies. They have an advantage for SMEs in that the learner does not need to physically attend classes and can access content as and when required (during periods of down time in work) It can take many forms (O'Driscoll, 2010; Horton, 2000).

- Entire content can be developed with sophisticated interactions and simulations to engage the user which require significant expertise.

- Alternatively basic content such as presentations, documents and other electronic material can be hosted on a learning content management system for the learner to read.

- Lectures or courses may be delivered via the web through computer mediated communication technologies such as adobe connect, recorded and hosted on a LCMS for the learner to listen to and view later.

With the emergence of MOOCs, web based training content is more accessible than ever allowing companies to utilise free content and expertise from prestigious institutes. This allows SMEs to access up to date knowledge from their own organisation as needed.

\subsection{Social Learning}

Social learning is a theory advocated by Bandura (1977) in which he stated that learning was achieved by observing, conversing, asking in formal and informal forms. This has major implication for SMEs favouring interaction and learn by doing approaches in addition to formal methods. SMEs must implement approaches to learning that allow employees to learn from each other and where the expertise is not available in house to connect with individuals that have that expertise. Technology such as social media now make this possible.

Social media allows companies to access up to date information as is needed, collaborate with external expertise and widen their skills base.

\subsection{Mobile Learning}

Mobile learning can allow SME managers and their employees to access information as needed just in time. With the significant technological advancement of mobile devices in recent years, mobile devices now provide texting, internet connection, diary's, email word processing packages, bar code readers just to name some functionality. This reduces the need for people to remain in a fixed location for work or learning (Peters, 2009). 
Mobile devices provide the ability to provide small amounts of information (in chunks) to the place as required. For example field workers can now access product information through mobile devices for the product they are maintaining. Kavakli (2003) investigated the use of chunking in strategic knowledge and found that experts processed information in smaller pieces. Mobile devices can facilitate this.

Again mobile learning can allow just in time learning allowing SMEs to be responsive and flexible to emerging needs.

As mentioned, Massive Open Online Courses (MOOCs) are a recent phenomenon in which university courses make their module and course content available freely online for learners to view. The learner can view the content but do not receive accreditation and take assessment unless they register for the course for a fee. McCualy et al. (2010) stated that, a "MOOC integrates the connectivity of social networking, the facilitation of an acknowledged expert in a field of study, and a collection of freely accessible online resources". This has huge advantages for SMEs, as e-learning often addresses many of the constraints they have with formal training however they are not concerned with accreditation more the applicability of the learning material. In addition they often struggle in creating digital content as they do not have the expertise in house to do this, in addition they find purchasing such expensive. Often they find whole university courses irrelevant and MOOCs allow them to take pieces from different university course to create a tailored course relevant to their needs. However the disadvantage is that harvesting relevant content and searching through the vast amounts of MOOCs for relevant content can be time consuming.

Many of these measures can facilitate sustainable learning in SMEs. However the success of formal learning is largely reliant on collaboration and sufficient guidance from a mentor. For SMEs this expertise may not always be in-house and they may need to leverage from external experts

\section{Mentoring}

Mentoring is a human research development approach where an existing member of staff or an external collaborator guides managers, newcomers or less-experienced people in a task to develop professional skills, attitudes and competencies. Mentoring is a key process for knowledge management. In a process of transferring tacit knowledge and retaining expertise within the organization, mentoring can also help the mentee to become a recognized and accepted member of the community, by passing on corporate vision and values and improving his grasp of corporate networking ( http://www.knowledge-management-tools.net/mentoring.html).

Eby (2008) highlighted three types of mentoring youth, academic and workplace mentoring. Of the three types of mentoring it was found that academic mentoring had the strongest association with outcomes, this may be due to the fact that it is targeted specifically at learning outcomes. Thus it is important to align mentoring programmes with actual outcomes in order for them to be of greatest success.

Mentoring offers a number of benefits for SMEs. Research has shown a positive influence on mentee performance (Fagenson-Eland et al., 1997, Barrett, 2006). Furthermore it addresses SMEs needs for timely, relevant training (Burgoyne \& Hodgson, 1983) and it does not require significant resources and is cost effective (Pawson, 2004). The most important benefits are a quickly introduction of new comers and support of integration of staff with special needs.

Mentors for SMEs have different backgrounds having general business/management competences, technical ones or sectoral specific experience.

Within SMEs that already use business mentors can play general roles across all areas of company business to a specific focus role, i.e., in the sales or marketing areas. Mentors can help to carry out a SWOT analysis including existing knowledge gaps and staff skills needs. Often SMEs need to strengthen their current market position before entering international markets with new products and need help in this transition.

Particularly important are mentors for first-time SME entrepreneurs in assembling teams, developing business plans, product development or sales and marketing strategies. They can help companies to prepare an investment plan and guide them in implementing this. All these are steps to sustainability.

Mentoring can support sustainable development by allowing SMEs to acquire knowledge from internal and external sources that will allow them to achieve their current strategies and create relationships that may help them in the future.

\subsection{Mentoring in Practice Ireland and Germany}

At the workshop organized during the project Net Knowing 2.0, SMEs from Germany proposed a route map for the successful deployment of a coaching and mentoring program in the specific context of a SME environment: 
- Putting the specific working environment into context.

- Researching the role played by the organizational culture or "climate" in the development, maintenance and success of the SME.

- Determining real qualification needs of the staff before starting the mentoring process.

- Determining the knowledge gaps and identifying which of them might be minimized by a mentoring system.

- Demonstrating that a mentoring intervention has real benefits in this context by not being bureaucratic.

- Developing a process based on trust, experience, and supervision and informal learning.

- Identifying barriers to effective mentoring/coaching.

- Determining issues that need to be incorporated within the mentoring/coaching intervention, if it is to be successful.

- Training coaches and mentors for different forms of working and learning.

- If necessary, using big companies to find mentors (learning consultants).

In Ireland the following factors were considered important.

- Linking mentoring to real learning outcomes.

- Developing a relationship of trust.

- Recognition of the time mentors invest in their mentees.

- Outlining guidelines for the mentoring process and emphasising the role of the mentor and mentee in the relationship.

- Changing the culture to make mentoring and learning "the norm" in the organization.

- When external mentors are required having a go to organisation (preferably a SME representative body) that will match SMEs with mentors in non-competing organizations.

\section{Communities}

SMEs have specific approaches to their target market with different motivation, experience and resources that influence their decision making processes (Nousala et al., 2010). Well-developed, sustainable internal or external communities and a good communication process become very important when considering particularly geographically dispersed SMEs, attempting to collaborate.

Some criteria to motivate companies to engage in communities are (Sustainable Communities, 2008):

- The company's reputation with customer, stakeholders, other companies is improved as it raises awareness of the company.

- Enhanced employees motivation, performance, skill development as new ways of doing business are learned and new skills are required from employees making their job more challenging.

- Enhanced staff retention and attractiveness to be employees as people are aware of the company and how they operate.

- Increased market share due to increased awareness of the company.

- Increased efficiency by cost saving which is achieved by implementing best practices learned through collaboration.

The benefits of collaboration can be demonstrated through the bullwhip effect in supply chain management. When organisations worked in isolation from their customers, suppliers, distributors and manufacturers there was a number of problems "excessive inventory, poor product forecasts, insufficient or excessive capacities, poor customer service due to unavailable products or long backlogs, uncertain production planning" (Lee et al., 1997). Communities allow SMEs to collaborate and learn best practices from each other; technology can be used as a medium to deliver these allowing SMEs to reach expertise from different geographical locations.

Some levels of integration in communities are on:

- Local

- National

- Marketplace (supply-chain interactions) 


\section{- International}

One of the approaches is a practice-oriented social Community of Practice-CoP (Wenger et al., 2002). Groups of people coming together to cooperate, solve problems, share knowledge, learn more informal from one another face-to-face and virtually in a community, which is open (Hamburg, 2013).

Of specific interest is the role of CoPs in developing sustainable areas through leveraging off the different experiences of $\mathrm{CoP}$ members and consensus on different levels.

Some positive aspects, which could be influenced by CoPs, are the followings:

- Improving the learning curve of new staff

- Supporting new ideas for solving problems

- Reducing rework and preventing "reinvention of the wheel"

- Responding more rapidly to customer needs and inquiries.

Through informal connections and learning that participants make in their CoPs, members acquire social capital, which gives value to individuals and to the group. In CoPs members share information, which is boundless; they learn how to convert theory into practice to solve practical problems. CoPs help participants to bridge the gap between tacit knowledge (How) and explicit knowledge (Lesser et al., 2001). They are an ideal mechanism for supporting different forms of learning.

Internet and social media web have a vast potential to create on-line virtual CoPs (VCoPs). Web 2.0 (O'Reilly, 2005) can efficiently support activities within a community. It also supports the collaboration of SME staff through interactive web-based services.

Social media based on Web 2.0 and 3.0 offer the place for a fast knowledge acquisition and support also within the communities (Hamburg, 2012a, 2012b). Kaplan and Heinlein (2009) created a classification scheme for different social media types in their Business Horizons article. According to them there are six different types of social media: collaborative projects, blogs and micro blogs, content communities, social networking sites, virtual game worlds, and virtual communities. Many of social media services can be integrated via social network aggregation platforms.

The use of social media with Web services and eLearning in CoPs improves the ability of members to socially interact with the technology used (communication with technology) and allows them to customize the content they are sharing online. CoPs developed with SME staff need not to be limited by geography or organizational departments; they can connect multiple departments where members experience problem solving strategies used by others; CoPs can include members for multiple organisations, fostering cooperation between business and government, education and business, professionals and volunteers.

In connection with communities, social media and the problem of integrating staff with special needs in companies, another form of learning should be promoted: social learning. Social learning theory is based on the fact that people learn within a social context. Social learning has a long tradition for personality development, particularly by students but it is not used in vocational training and SMEs. It aims to develop interaction and communication skills as well as cooperation and conflict-management skills (Dewey, 1916). Web technologies support a social learning with online components. One form of social learning is during mentoring processes.

\section{Conclusions}

This paper highlighted the need for SMEs to have a sustainable approach to development. It posed the question can training and collaboration support sustainable development in SMEs. The paper explored the use of different forms of training that will allow SMEs to develop the skills to satisfy their future and emerging needs. Problem based learning, web based learning and social learning were examined in terms of their ability to support this requirement. Mentoring literature and practices and communities were explored as a means of facilitating collaboration to support the above research question.

\section{References}

Aderinto J., Aderinto C., \& Akande, J. (2008). Collaboration in Distance Education: Problems, Benefits and Prospects. The International Journal of Technology, Knowledge and Society, 4(82), 87-92.

Admiraal, W., \& Lockhorst, D. (2009). E-Learning in Small and Medium-sized Enterprises across Europe: Attitudes towards Technology, Learning and Training. International Small Business Journal, 27, 743. http://dx.doi.org/10.1177/0266242609344244 
Ashton, D. N., \& Felstead, A. (1995). Training and Development. In Human Resource Management: A Critical Text. London: Routledge.

Bandura, A. (1977). Social Learning Theory. General Learning Press.

Barrett, R. (2006). Small business learning through mentoring: Evaluating a project. Education + Training, 48(8/9), 614-626. http://dx.doi.org/10.1108/00400910610710047

Barron, J., Berger, M., \& Black, D. (1999). Do Workers Pay for On-the-Job Training. The Journal of Human Resources, 34(21), 236-252.

Bell, S. (2010). Project-Based Learning for the 21st Century: Skills for the Future. The Clearing House: A Journal of Educational Strategies, Issues and Ideas, 83(2), 39-43. http://dx.doi.org/10.1080/00098650903505415

Black, S., \& Lynch, L. (1996). Human Capital Investments and Productivity. American Economic Review, 1996(May), 263-267.

Blundell, R., Dearden, L., Meghir, C., \& Sianesi, B. (1999). Human Capital Investment: The Returns from Education and Training to the Individual, the Firm and the Economy. Fiscal Studies, 20(1), 1-23. http://dx.doi.org/10.1111/j.1475-5890.1999.tb00001.x

Burgoyne, J., \& Hodgson, V. (1983). Natural learning and managerial action: A phenomenological study in a $\begin{array}{lllll}\text { field setting. Journal of Management } & \text { Studies, } & \text { 20(3), } & \text { 87-99. }\end{array}$ http://dx.doi.org/10.1111/j.1467-6486.1983.tb00214.x

Cho, K. L., \& Jonassen, D. H. (2002). The effects of argumentation scaffolds on argumentation and problem solving. ETR \& D, 50(3), 5-22. http://dx.doi.org/10.1007/BF02505022

Conti, G. (2004). Training Productivity and Wages. The sixteenth annual European Association of Labour Economists (EALE), 2004, Lisbon, Portugal.

Dewey, J., \& Oelkers, J. (Eds.). Demokratie und Erziehung. Weinheim 1916/1993.

Donnelly, R. (2006). Blended problem-based learning for teacher education: Lessons learnt learning. Media and Technology, 31(2), 93-116. http://dx.doi.org/10.1080/17439880600756621

Downes, S. (2010). New Technology Supporting Information Learning. Journal of Emerging Technologies in Web Intelligence, 2(1). http://dx.doi.org/10.4304/jetwi.2.1.27-33

Eby, L., Allen, T., Evans, S., Ng, T., \& DuBois, D. (2008) Does mentoring matter? A multidisciplinary meta-analysis comparing mentored and non-mentored individuals. Journal of Vocational Behavior, 72, 254-267. http://dx.doi.org/10.1016/j.jvb.2007.04.005

European Commission. (2003a). Competence Development in SMEs. European Observatory for SMEs, European Commission.

European Commission. (2003b). SMEs in Europe 2003. European Observatory for SMEs, European Commission.

Fagenson-Eland, E. A., Marks, M. A., \& Amendola, K. L. (1997). Perceptions of mentoring relationships. Journal of Vocational Behaviour, 51, 29-42. http://dx.doi.org/10.1006/jvbe.1997.1592

Filiatrault, P., Harvey, J., \& Chebat, J. (1996). Service Quality and Service Productivity Management Practices. Industrial Marketing Management, 25. http://dx.doi.org/10.1016/0019-8501(95)00129-8

Gay, B. (1994). What is Mentoring? Education and Training, 36(5), 4-7. http://dx.doi.org/10.1108/00400919410062257

Hamburg, I. (2012a). Innovative e-learning solutions and environments for small and medium sized companies (SMEs). In P. Ghislandi (Ed.), Elearning: Theories, design, software and applications (pp. 53-72). Rijeka: InTech. http://dx.doi.org/10.5772/29986

Hamburg, I. (2012b). Using informal learning, e-learning, and cooperation in SMEs. International journal of e-business development, 2(2), 28-31.

Hamburg, I. (2013). Facilitating learning and knowledge transfer through mentoring. In CSDU 2013: 5th International Conference on Computer Supported Education; Aachen, ermany, 6-8 May, 2013. Lissabon: Science and Technology Publications, 4.

Hamburg, I. (2013). Knowledge transfer through diversity coach and mentoring partnership. In R. J. Howlett, B. 
Gabrys, K. Musial-Gabrys, \& J. Roach (Eds.), Innovation through knowledge transfer 2012 (pp. 107-119). Heidelberg: Springer. http://dx.doi.org/10.1007/978-3-642-34219-6_13

Hankinson, A. (1994). Small Firms' Training: The Reluctance Prevails. Industrial and Commercial Training, 26(9), 28-30. http://dx.doi.org/10.1108/00197859410065889

Hmelo, C. E. (1998). Problem-based learning: Effects on the early acquisition of cognitive skill in medicine. The Journal of the Learning Sciences, 7(2), 173-208. http://dx.doi.org/10.1207/s15327809j1s0702_2

Hoffman, B., \& Ritchie, D. (1997). Using multimedia to overcome the problems with problem based learning. Instructional Science, 25, 97-115. http://dx.doi.org/10.1023/A:1002967414942

Holzer, H., Block, M., \& Knott, J. (1993). Are Training Subsidies for firms Effective? The Michigan Experience. Industrial and Labor Relations Review, 46(4), 625-636. http://dx.doi.org/10.2307/2524308

Horton, W. (2002). Designing web based training. Wiley.

Jonassen, D. H. (1997). Instructional design models far well-structured and ill-structured problem solving learning outcomes. Educational Technology Research and Development, 45(1), 65-94. http://dx.doi.org/10.1007/BF02299613

Jonassen, D. H. (2000). Toward a Design Theory of Problem Solving. Educational Technology Research and Development, 48(4), 63-85. http://dx.doi.org/10.1007/BF02300500

Kaplan, A. M., \& Haenlein, M. (2009). Users of the world, unite! The challenges and opportunities of Social Media. Business Horizons, 53(1), 59-68. http://dx.doi.org/10.1016/j.bushor.2009.09.003

Kavakli, M., \& Gero, J. S. (2003). Difference between expert and novice designers: An experimental study. In U. Lindemann (Ed.), Human Behaviour in Design. http://dx.doi.org/10.1007/978-3-662-07811-2_5

Kim, Y, Sohn, D., \& Choi, S. M. (2011). Cultural difference in motivations for using social network sites: A comparative study of American and Korean college students. Computers in Human Behaviour, 27. http://dx.doi.org/10.1016/j.chb.2010.08.015

Kok, J., Vroonhof, P., Verhoeven, W., Timmermans, N., Kwaak, T., Snijders, J., \& Westhof, F. (2011). Do SMEs create more and better jobs? EIM Business \& Policy Research with financial support from the European Communities, under the Competitiveness and Innovation Programme.

Konrad, A. M., \& Mangel, R. (2000). The Impact of Work-Life Programs on Firm Productivity. Strategic $\begin{array}{lll}\text { Management Journal, } & \text { 21(12), }\end{array}$ http://dx.doi.org/10.1002/1097-0266(200012)21:12<1225::AID-SMJ135>3.3.CO;2-V

Kram, K. E., \& Bragar, M. C. (1991). Career Development through Mentoring. A Strategic Approach for the 1990s. Mentoring International, 5(1-2).

Lee, H., Padmanabhan, V., \& Whang, S. (1997). The Bullwhip Effect in Supply Chains. Sloan Management Review, 38(Spring).

Lesser, L. E., \& Storck, J. (2001). Communities of Practice and organizational performance. 40. IBM Systems Journal. Retrieved from http://www.providersedge.com/docs $/ \mathrm{km} \_$articles/ CoP_and_Organizational_Performance.pdf

Mazzarol, T., Reboud, S., \& Tye, M. (2006). The Outsiders Role in the Strategic Development of the Small Firm: A Study of Mentoring with Small Business Owner-Managers in Australia. Reaching New Heights-Administrative Sciences Association of Canada Annual Conference, Banff, Canada 4-6 June 2006.

McAuley, A., Stewart, B., Siemens, G., \& Cormier, D. (2010). The MOOC Model for Digital Practice Research report for the Social Sciences and Humanities Research Council's "Knowledge Synthesis Grants on the Digital Economy".

McLinden, M., McCall, S., Hinton, D., Weston, A., \& Douglas, G. (2006). Developing online problem-based resources for the Professional development of teachers of children with visual impairment. Open Learning, 21(3), 237-251. http://dx.doi.org/10.1080/02680510600953211

Moorby, E. (1992). Mentoring and Coaching. In J. Prior (Ed.), Gower Handbook of Training and Development (p. 421). Worcester, GB: Billing Sons Ltd.

Nottingham Trent University. (2002). Barriers to Training in Small and Medium Sized Enterprises. Nottingham: Learning and Skills Council. 
O’Driscoll, M. (2010). Web based training: Creating e-learning experiences. Jossey-Bass/Pfieffer.

O'Reilly, T. (2005). What is Web 2.0. Design patterns and Business models for the next generation of Software. Retrieved from http://www.oreillynet.com/lp/a/6228

Pawson, R. (2004). Mentoring relationships: A review of the evidence. Working Paper 21, ESRC UK Centre for Evidence Based Policy and Practice, Swindon.

Peters K. (2009). Mobile Learning: Positioning educators for a Mobile Connected Future. In M. Ally (Ed.), Mobile Learning: Transforming the Delivery of Education and Training. Athabasca University.

Porter, M. E. (1985). Competitive advantage: Creating and sustaining superior performance. New York: Free Press.

Ravenscroft, A. Schmidt, A., Cook, J., \& Bradley, C. (2012). Designing social media for informal learning and knowledge maturing in the digital workplace. Journal of Computer Assisted Learning, 28, 235-249. http://dx.doi.org/10.1111/j.1365-2729.2012.00485.x

Richert, V. (2006). Mentoring und lebenslanges Lernen. Individuelles Wissensmanagement im Informationszeitalter. Müller, Saarbrücken.

Sendag, S., \& Odabas, H. F. (2009). Effects of an online problem based learning course on content knowledge acquisition and critical thinking skills. Computers \& Education, 53, 132-141. http://dx.doi.org/10.1016/j.compedu.2009.01.008

Siemens, G. (2005). Connectivism: A learning theory for the digital age. International Journal of Instructional Technology and Distance Learning. Retrieved from http://www.idtl.org/Journal/Jam_05/article01.htm

Stainer, A. (1997). Capital Input and Total Productivity Management. Management Decision, 35(3), 224-232. http://dx.doi.org/10.1108/00251749710169431

Stone, I. (2010). Encouraging small firms to invest in training: Learning from overseas, Praxis UK commission for employment and skills.

Storey, D. J., \& Westhead, P. (1997). Training Provision and the Development of Small and Mediums Sized Enterprises.

Walters, R., \& Sirotiak, T. (2011). Assessing the effect of project based learning on leadership abilities and communication skills. 47th ASC Annual International Conference Proceedings

Wenger, E., McDermott, R., \& Snyder, W. M. (2002). Cultivating Communities of Practice (1st ed.). Boston, MASS: Harvard Business Press.

Wood, D. F. (2003). ABC of learning and teaching in medicine: Problem based learning. British Medical Journal, 326, 328-330. http://dx.doi.org/10.1136/bmj.326.7384.328

Wynn, P. (1992). Computer Based Training. In J. Prior (Ed.), Gower Handbook of Training and Development (p. 384). Worcester, GB: Billing Sons Ltd.

Zey, M. G. (1989). Building a Successful Formal Mentor Program. Mentoring International, 3(1).

\section{Copyrights}

Copyright for this article is retained by the author(s), with first publication rights granted to the journal.

This is an open-access article distributed under the terms and conditions of the Creative Commons Attribution license (http://creativecommons.org/licenses/by/3.0/). 